\title{
AS INVASÕES \\ BÁRBARAS OU A \\ RACIALZAÇÃO DA \\ HISTÓRIA DA ARTE
}

LES INVASIONS

BARBARES OU LA

RACIALISATION DE

LHISTOIRE DE LART

BARBARIAN

INVASIONS AND THE BACIALIZATION OF

ÉRIC MICHAUD

ART HISTORY 
1. Tradução do capítulo “As invasões bárbaras ou a racialização da História da Arte", publicado no livro Les invasions barbares: une généalogie de l'histoire de l'art (Éditions Gallimard, 2015), de Éric Michaud.

2. A seleção do conjunto de títulos apresentados aqui pela primeira vez em versão brasileira resultou das discussões do grupo de estudantes, assistentes

editoriais e editoras que organiza este número especial de Ars, e que transcorreram num período de cerca de um ano e meio antecedendo o lançamento desta edição; a iniciativa visa ampliar 0 acesso dos pesquisadores brasileiros estudantes de graduação e pós-graduação a autores lugar de uma Europa livre e rica, teríamos apenas uma Roma onde tudo seria confundido, misturado. No lugar da história dos reinos europeus, teríamos apenas os anais de um império romano, que nos ofereceria a triste uniformidade das crônicas chinesas.

FRIEDRICH SCHLEGEL, 1809

Sim, nós somos orientais - pela raça. Somos duplamente orientais tanto por nossa origem céltica quanto por nossas incursões germânicas do século IV ao século X. Somos latinos e greco-romanos apenas pela educação literária. LOUIS COURAJOD, 1891

Um modelo histórico e cultural de potência e longevidade notáveis estruturou, por suas dimensões propriamente míticas, a escrita da história da arte na Europa desde o começo do século XIX. Surpreendentemente, a historiografia da arte pouco lhe prestou atenção, apesar de ele ter deixado marcas profundas no campo, que se estendem até as categorias pelas quais a disciplina buscou classificar cientificamente seus objetos. Até a publicação da monumental 
History of the Decline and Fall of the Roman Empire (1776-1788), de Edward Gibbon, debateu-se longamente no século XVIII, sobretudo na França, o verdadeiro papel dos "bárbaros” na construção das nações europeias, sem que nunca, até então, as "invasões bárbaras" tivessem ocupado o lugar de pivô da história ocidental ou, mais ainda, nunca tivessem sido pensadas como a origem ou matriz dos conflitos presentes. Foi apenas no retorno dos tempos bárbaros ao coração do romantismo europeu - em reação às Luzes, à Revolução Francesa e ao Império Napoleônico - que a oposição das "raças germânicas" às "raças latinas" se constituiu como o modelo de interpretação mais corrente das produções culturais ${ }^{1}$, um modelo tão usual que se tornou praticamente invisível na literatura da arte, na qual até hoje está presente. Assim, faz-se necessário esboçar aqui a emergência desse modelo e seu alcance no pensamento de alguns historiadores da arte que contribuíram na fundação da disciplina.

Na base da antítese geográfica e climática entre Norte e Sul, logo se instalou um verdadeiro arsenal de oposições, herdado do século XVIII, que o século XIX vai desenvolver com uma constância impressionante, e que o século seguinte acentuará ainda mais ${ }^{2}$. Resumidamente, a velha Europa romana, feminina e decadente, devia à energia viril dos jovens povos do Norte - os famosos bárbaros - sua 
regeneração e entrada na modernidade. Foram eles que fizeram a história da Europa voltar-se do Sul para o Norte, propagando uma religião cristã que logo souberam encarnar numa arte denominada quase indistintamente de romântica, gótica ou germânica, e que se opunha em quase todos os pontos ao classicismo da Antiguidade mediterrânea. Havia sido, então, graças aos povos do Norte que a Europa pôde superar o paganismo antigo, escapando assim do taciturno classicismo dos latinos e da normatividade esmagadora de Roma, que sufocava o espírito dos povos que ela havia conquistado. O Norte era, enfim, "a fábrica dos instrumentos que quebram os grilhões forjados no Sul”, como escreve Montesquieu (1748, livro XVII, cap. V).

\section{DESBARBARIZAR OS BÁRBAROS}

Roma e os bárbaros: o modelo foi imediatamente transponível para a Europa de Napoleão, sobretudo após 1806, com o fim do Sacro Império Romano-Germânico e a ocupação de parte da Prússia pelas tropas de Napoleão. Herder, cuja ideia de que seria necessário opor uma outra história àquela escrita pelos vencedores chegara à Alemanha ocupada, descreve a queda de Roma como 
uma quebra no fio dos acontecimentos universais! Seria necessário nada menos que um mundo novo para remediar essa quebra. Esse foi o Norte. Enquanto tudofinalmente ruía, queinundação do Sul pelo Norte! Edepois de todas as tormentas, de todos os horrores, que mundo novo, nórdico e meridional! [...] Tudo estava esgotado, enervado, deslocado. [...] Então nasceu no Norte um novo homem, [...] godos, vândalos, burgúndios, anglos, hunos, hérulos, francos e búlgaros, eslavos e lombardos chegaram, se estabeleceram, e todo o mundo novo, do Mediterrâneo ao Mar Negro, do Atlântico ao Mar do Norte, é sua obra! Sua raça! Sua constituição! (HERDER, [1774]1943, pp. 195-197)

Após 1806, no entanto, a escrita dessa outra história não mais reunia o Norte e o Sul, mas, ao contrário, opunha-os, frequentemente acentuando-lhes os traços irredutíveis. Um dos mais ativos artesãos dessa oposição extrema foi certamente Friedrich Schlegel. De início admirador fervoroso do helenismo, logo ele seria persuadido de que havia chegado o momento de fundar uma nova religião, da qual Novalis seria Cristo, e ele, "seu valente São Paulo". A partir de maio de 1799, Schlegel daria a esse "projeto bíblico" uma dimensão escatológica e purificadora: assim como o cristianismo primitivo havia, contra todas as probabilidades, engolido o Império Romano, "da mesma maneira essa nova grande catástrofe, espalhando-se cada 
vez mais, absorverá a Revolução Francesa, cujo mais sólido mérito terá sido justamente o de provocá-la" (apud SPENLÉ, 1904, pp. 244-245)3. Em 1804, ao visitar a basílica de Saint-Denis em ruínas, Schlegel sonhava melancolicamente com os "tempos antigos em que a França foi conquistada e governada pelos alemães [von Deutschen erobert und beherrscht]" e pensava que deveria ser chamado de "arquitetura alemã" o estilo gótico que era comum a todos os povos germânicos (SCHLEGEL, 1806, pp. 267; 278).

Seis anos mais tarde, a serviço de Metternich, Schlegel lecionaria história contemporânea em Viena. Fichte, nos Discursos à nação alemã - então recém-proferidos em Berlim, em 1807 e 1808 -, compararia os franceses na conquista da Prússia aos romanos do século I, convidando os alemães a resistir da mesma maneira como outrora fizeram os germanos. No ano seguinte, Friedrich Schlegel faria, por sua vez, da época das invasões a verdadeira chave que permitiria compreender o tempo presente - e viceversa: se o passado permitia julgar com clareza o presente, dizia Schlegel, o presente dissipava a obscuridade do passado: "Quantas páginas da história até então incompreendidas não nos foram agora esclarecidas graças aos acontecimentos dos últimos anos”! Assim, a migração dos povos, representada comumente como "uma espécie 
de fluxo de hordas bárbaras", teria sido apenas uma luta entre os germanos e Roma - algo que a chegada dos hunos, em número limitado, nada modificou. Para restabelecer enfim a verdade, seria necessário desbarbarizar os bárbaros, ou seja, destruir a opinião injusta, mas tão disseminada, de que os antigos germanos eram "povos totalmente bárbaros", comparáveis aos selvagens da América. Somente então esse fenômeno, que franceses e italianos se obstinaram em designar como "invasões bárbaras", poderia ser visto em todo seu esplendor e importância decisiva: "A migração dos povos é a linha de demarcação entre o mundo antigo e o novo" [Die Völkerwanderung ist die Scheidewand zwischen der alten und der neuen Welt], escreve Schlegel.

Desse evento extraordinário e de consequências incalculáveis resulta a história moderna da Europa: se as migrações não tivessem acontecido, se os "povos alemães" não tivessem repelido o jugo romano, "o resto do Norte da Europa teria certamente sido incorporado por Roma, a liberdade e o gênio próprios a essas nações teriam sido apagados [...] e a mesma uniformidade teria invadido todas essas províncias" (SCHLEGEL, 1811, pp. 10-11). Em vez da Europa livre, rica e diversa que conhecemos, tudo seria confundido e misturado numa Roma uniformemente triste. A migração dos povos, 
afirma Schlegel, não era nada além da "história da guerra entre os povos livres da Germânia e os romanos mestres do mundo: guerra que terminaria apenas com a queda de Roma e os fundamentos das primeiras nações" (Idem, 1831, t. I, pp. 75-76; 34; 8-10). Nessas propostas e teses vindas de Viena, qualquer um poderia enxergar uma clara advertência lançada ao Império de Napoleão I, novo mestre do mundo.

Esse mesmo espírito estava encarnado no livro sobre a Alemanha de Madame de Staël, que, publicado em 1813 e traduzido em 1814 para o inglês, alcançou considerável sucesso, disseminando assim algumas dessas principais proposições por toda a Europa. Germaine de Staël, no entanto, tomou-as emprestado tanto de Friedrich Schlegel quanto das aulas do Curso de literatura dramática que seu irmão, August Wilhelm, havia ministrado também em Viena, perante um auditório entusiasta do qual ela mesma fazia parte 4 . Essa foi, sem dúvida, a primeira vez que o espaço europeu da literatura e das belas-artes foi racializado ${ }^{5}$. Longe de qualquer ambiguidade, Da Alemanha de fato abria com uma divisão da Europa segundo "três grandes raças diferentes: a raça latina, a raça germânica e a raça eslavônica”. Desconsiderando a raça dos eslavos por considerá-la uma mera imitadora, de Staël considerava que "a Europa 
literária" estava separada em "duas grandes divisões bem-marcadas": "A literatura que imita os antigos e aquela cujo nascimento se deve ao espírito da Idade Média; a literatura que, em sua origem, recebeu do paganismo a cor e o charme e a literatura cujo impulso e desenvolvimento pertencem a uma religião essencialmente espiritualista”. De Staël delinearia uma psicologia das raças bastante elementar que prolongava a tradição do "caráter nacional" desenvolvida no século precedente. Evidentemente, a guerra entre os povos livres germânicos e os romanos mestres do mundo se prolongava sob seus olhos, cindindo a Europa em duas. Italianos, franceses, espanhóis e portugueses herdavam do paganismo dos romanos a civilização, a língua, o gosto pelos prazeres e pelas coisas terrenas. "Esses povos, assim como seus mestres, os romanos, conhecem apenas a arte da dominação”. No Norte, alemães, suíços, ingleses, suecos, dinamarqueses e holandeses pertenciam às "nações germânicas", que "quase sempre resistiram ao jugo dos romanos". Civilizadas mais tarde pelo cristianismo, essas nações "passaram imediatamente de uma espécie de barbárie à sociedade cristã”. O mesmo caráter, por fim, era sempre encontrado entre os diversos povos de origem germânica, sempre independentes e leais, bons e fiéis (DE STAËL, [1813] 1859, "Observations générales") ${ }^{6}$. A partir 
da conquista dos povos do Sul pelos povos do Norte, nada ou quase nada mudou no caráter de ambos, exceto que - e esse é um ponto essencial - os povos outrora conquistadores agora queixavam-se de serem os oprimidos.

Ao definir o termo romântico, "recentemente introduzido na Alemanha" (de onde viria?), de Staël lista os pares de antagonistas que, segundo ela, dividiam o império da literatura: "O paganismo e o cristianismo, o Norte e o Sul, a Antiguidade e a Idade Média, a cavalaria medieval e as instituições gregas e romanas”. Qualquer um que rejeitasse essa divisão estaria não somente impedido de julgar "o gosto antigo e o gosto moderno", mas também de compreender que essa divisão estava relacionada "igualmente às duas eras do mundo: a que precedeu o estabelecimento do cristianismo e a que se seguiu" (Ibidem, segunda parte, capítulo XI). O livro de propagan$\mathrm{da}^{7}$ de Madame de Staël essencialmente transmitia aos franceses a clara noção de que a guerra que opunha os românticos e os clássicos repetia e prolongava simultaneamente a guerra que havia oposto germanos e romanos, cristianismo e paganismo. Antes mesmo que se iniciassem as "guerras de liberação" (as Befreiungskriege de 1813-1815) da Prússia contra o Império de Napoleão, o romantismo já havia iniciado a guerra contra a ordem clássica. O futuro estava 
do seu lado, assim como antes, contra Roma, do lado dos germanos. O romantismo pensava a si mesmo como uma transgressão formal, como um arroubo estético e formal lançado por um gênio oprimido, mas popular, jovem e vigoroso, contra as regras restritivas de uma Roma uniformemente triste, cujo colapso ele certamente provocaria. Assim, o pintor romântico Caspar David Friedrich se definia como "a ponta de lança da barbárie, negra como a noite, avançando orgulhosamente, pisoteando com desprezo todas as regras, as correntes, os laços que subjugam a mente e que a mantêm na trilha já aberta"».

As duas versões das “invasões bárbaras” que forneciam à França è̀ Alemanha seus mitos de origem conheceram, então, uma nova juventude: de um lado, as "invasões bárbaras" e a "conquista franca"; de outro, a "migração dos povos" ou Völkerwanderung, ou seja, a migração dos antigos germanos tal como fora idealizada na Germânia de Tácito9. Evidentemente, as línguas transmitiram diferentes versões da história. A língua francesa registrou as incursões, agressões e ocupações, enquanto a alemã preferiu reter a ideia mais neutra de um deslocamento de povos. Enquanto na França o termo “invasões bárbaras” significaria essencialmente as “invasões germânicas" do século V que originaram o Regnum Francorum, por muito tempo historiadores de língua alemã tomariam o cuidado de 
distinguir os "antigos germanos" dos "bárbaros”. De fato, entre alemães e franceses operava-se uma peculiar troca de papéis. Ao longo de todo o século XVIII, a cultura da Corte e das elites era, nos Estados alemães, quase inteiramente dominada pela cultura francesa, ao passo que na França se construía uma teoria das "duas raças" que, atribuindo uma origem franca à aristocracia, situava os "germanos" como os verdadeiros mestres de um povo francês essencialmente "gaulês". O classicismo dos latinos impunha a lei estética e ideológica no espaço germânico, mas o "sangue germânico" impunha a lei civil e política a um povo "latino" ou "galo-romano". Assim, de ambos os lados um conflito entre raças se duplicava em um conflito entre classes: no espaço germânico, denunciava-se a cultura francesa e clássica das elites cultivadas que as tornavam estrangeiras ao povo alemão, enquanto na França a aristocracia logo foi denunciada por sua origem germânica, de maneira que, dos dois lados, as hierarquias de "raças" pareciam se confundir com as hierarquias sociais.

No começo do século XVIII, o Conde de Boulainvilliers buscou estabelecer as invasões bárbaras como o mito de origem da nobreza. Diferentemente do povo, a nobreza francesa descenderia dos francos, uma coalisão de diferentes povos germânicos, detendo, portanto, os direitos provindos da conquista da Gália romana, 
no século V. Arma política destinada à manutenção e fortalecimento dos direitos da aristocracia contra a aliança da monarquia com a burguesia (o terceiro estado), esse mito de origem colocava os nobres como os livres "companheiros" e "iguais" do rei, enquanto os "gauleses" seriam os súditos de uma nobreza germânica, "tanto pelo direito de conquista quanto pela necessidade de obediência ao mais forte". Em 1789, o abade Sieyès ironicamente inverteria o argumento em um célebre panfleto, no qual ameaçava os bárbaros de expulsão: "Por que [o terceiro estado] não manda de volta para as florestas da Francônia todas essas famílias que mantêm a tola pretensão de serem fruto da raça dos conquistadores e de terem deles herdado os direitos"? Com isso, no entanto, o abade apenas buscava demonstrar como a liberdade não era um privilégio de nascimento, mas um direito de todos, uma vez que ter nascido gaulês ou romano valeria tanto quanto descender de sicambros e de "outros selvagens saídos dos bosques e lagos da antiga Germânia" (SIEYĖS [1789] 1888, pp. 32-33).

Com a queda do Império Napoleônico, a Restauração da monarquia e o retorno à França de uma nobreza emigrada que, tal como Montesquieu, era convicta de sua origem germânica, o tempo dos bárbaros parecia se confundir totalmente com o tempo da 
modernidade romântica: de uma só vez, poder-se-ia jogar na lixeira da história não apenas a Revolução Francesa, identificada com Roma e o classicismo que a figurou, mas também as "raças latinas" que o haviam encarnado. A decadência de ambos repetia a de Roma: por toda parte ouvia-se que o tempo deles havia acabado, ao passo que começava ou recomeçava o das "raças germânicas", ao mesmo tempo que o cristianismo renascia na Europa. Após o Congresso de Viena e o desmantelamento do efêmero Império Napoleônico, a reação foi indissociavelmente religiosa e política, cultural e artística. Em 1824, Sulpiz Boisserée, pouco depois de reafirmar a origem exclusivamente germânica do estilo gótico, se regozijou com o fato de os franceses terem sido vencidos "não apenas no âmbito militar, mas no âmbito moral, literário e artístico", sendo forçados até mesmo na pintura a "aceitar os temas religiosos" (apud MOISY, 1956, p. 129). Pouco depois, o Barão de Eckstein, retomando a oposição do clássico ao romântico traçada pelos irmãos Schlegel, sublinharia o quanto essas divergências não resultavam somente das diferenças religiosas, mas também das nacionalidades, "helênica de um lado e germânica do outro. Toda a Europa outrora latina é agora germânica, pois os povos do Norte fundaram todos os impérios meridionais, para os quais eles levaram seu gênio e caráter próprios” (D’ ECKSTEIN, 1826, t. II, p. 41). 
Trinta anos mais tarde, o eminente germanista Philarète Chasles contemplaria a história do alto de sua cadeira no Collège de France: "O elemento germânico progride há dois séculos; o elemento romano perece de todos os lados". Napoleão, homem do Sul, foi seu último e sublime representante, armando-se e organizando-se contra um mundo germânico "cuja ascensão ele previa" (CHASLES, 1854, p. 6).

Tudo isso significava, no entanto, que, se as raças latinas estavam visivelmente em declínio, as raças germânicas não haviam ainda cumprido a tarefa que a história lhes havia incumbido. A Catedral de Colônia era o símbolo mais gritante da consciência dessa incompletude. Segundo Sulpiz Boisserée, o monumento suscitava simultaneamente a admiração e o arrependimento: era "o mais grandioso, o mais imponente, o mais perfeito de todas as épocas”, mas os guindastes, que esperavam há três séculos para completar o topo da torre, evocavam irresistivelmente os infortúnios que impediram, na realidade, o acabamento ou a completude nacional (BOISSERÉE, [1823] 1843, p. VII). Enquanto o classicismo romano não terminava de morrer, o romantismo germânico não cessava de nascer. 


\section{INVERSÕES ROMÂNTICAS}

Hannah Arendt sublinha que os franceses, ao herdarem o mito racial de uma nobreza fundada na "invasão franca", foram os primeiros na Europa a manifestarem a obsessão pela superioridade germânica sobre a qual posteriormente se instalaram as teorias raciais francesas (ARENDT, 2012, pp. 240-241). Em 1820 - mesmo ano em que Guizot escrevia que, após 13 séculos de luta, a Revolução havia sido a batalha decisiva que libertou a França da "raça conquistadora" e da "raça conquistada" (GUIZOT, 1820, pp. 1-2) -, Augustin Thierry observou a "antipatia de raça" que ainda dividia a nação francesa: "O gênio da conquista brincou com a natureza e o tempo. Ele paira ainda sobre essa terra infeliz" (Idem, [1820] 1851). De fato, Thierry logo afirmaria que quase todos os povos da Europa carregam as marcas das conquistas da Idade Média, ou seja, as classes superiores e inferiores de hoje nada seriam além dos povos conquistadores e os povos dominados de uma época anterior: "A raça dos invasores permaneceu como uma classe privilegiada, a partir do momento que ela deixou de ser uma nação à parte" (THIERRY, [1825] 1846, t. I, p. 8) ${ }^{11}$. 
Desde o século XVIII, a dominação europeia sobre os povos dos outros continentes passava por uma consequência natural de sua superioridade e da "desigual perfectibilidade das raças humanas”. Agora, as obras de Augustin Thierry e de seu irmão, Amédée (cuja Histoire des Gaulois foi publicada em 1819) propagavam a convicção de que a própria história da Europa era, em última análise, inteligível apenas sob a condição de compreender que, também na Europa, as raças eram verdadeiras forças coletivas que haviam feito e continuavam a fazer história. A nova fascinação de antropólogos, filósofos, economistas e historiadores pela versão europeia da "questão das raças" foi acompanhada de um amplo movimento de desbarbarização dos antigos bárbaros ${ }^{12}$. Cada vez mais se multiplicavam as teorias científicas que buscavam provar a inferioridade natural dos povos selvagens ou colonizados pelos europeus, assim como se tornava cada vez mais necessário reabilitar as "raças bárbaras" que, segundo Chateaubriand, haviam afinal formado na Europa "o ponto de contato em que a história dos Antigos e dos Modernos se une" (CHATEAUBRIAND, [1797] 1836, t. II, 1, p. 11, nota 1$)^{13}$.

A reabilitação dos bárbaros também era certamente uma justificativa para a colonização, como Aimé Césaire não se enganou 
em dizer. Para demostrar "como a colonização trabalha para descivilizar o colonizador, para literalmente embrutecê-lo, degradá-lo, despertar-lhe instintos escondidos para a ganância, a violência, o ódio racial, o relativismo moral", e mostrar que, no fim, o que se encontra é "o veneno instilado nas veias da Europa e o progresso lento, mas seguro, do enselvajamento do continente", Césaire cita A Reforma intelectual e moral que Renan escreve no dia seguinte à Batalha de Sedan: "A regeneração das raças inferiores ou bastardas pelas raças superiores está na ordem providencial da humanidade" (CÉSAIRE, 1955, pp. 12;15) ${ }^{14}$. Além disso, Renan legitima explicitamente a colonização por meio do exemplo da "conquista germânica": "A colonização é uma necessidade política de primeiríssima ordem. Uma nação que não coloniza está irrevogavelmente condenada ao socialismo, à guerra do rico e do pobre. A conquista de um país de raça inferior por uma raça superior que ali se estabelece para governar não tem nada de chocante. [...] A conquista germânica dos séculos V e VI se tornou na Europa a base de toda conservação e legitimidade. Do mesmo modo, as conquistas entre raças iguais devem ser condenadas, assim como a regeneração das raças inferiores ou bastardas pelas raças superiores está na ordem providencial da humanidade" (RENAN, 1871, pp. 92-93). 
Quarenta anos antes e sob uma perspectiva totalmente diferente, Michelet se tornou um dos mais ferrenhos defensores da reabilitação dos bárbaros. A esse respeito, o prefácio de História Romana é exemplar. Nele, Michelet opõe a vitalidade revigorante do Norte à secura do Sul: "Se você quiser a vida e o frescor, vá para o Norte, para o meio das florestas sem fim e sem limite, sob carvalhos verdes regados lentamente por longas chuvas. Ali se encontram ainda as raças bárbaras, de cabelos loiros, faces frescas e juventude eterna. Esta é a maneira pela qual eles rejuvenescem o mundo. Roma foi renovada pela invasão dos homens do norte, e foi preciso um homem do norte, um bárbaro, para renovar a história de Roma”. Assim Michelet introduziu em 1931 a figura de Barthold Georg Niebuhr, grande historiador da Antiguidade romana falecido pouco antes em Bonn, que havia compreendido melhor “a velha Roma bárbara, da qual trazia algo em si”. E a ele pertencia, insiste Michelet, “a glória de ter, desde 1812 (12 anos antes da obra admirável de Thierry), compreendido toda a importância da questão das raças" (MICHELET, 1831, t. I, pp. IX-XI).

No campo da arte e de sua história, o duradouro movimento de reabilitação dos bárbaros foi contemporâneo da redescoberta do estilo "gótico" e do longo período em que o estilo esteve em 
voga, causando notáveis consequências. Desde o fim do século XVI, a tradição buscava imputar aos góticos, como afirmava Vasari (1981, t. I, p. 101), a "destruição das construções antigas e a morte dos arquitetos nas guerras" ${ }^{15}$. Émeric-David foi um dos primeiros na França a se insurgir contra essa noção preconceituosa: longe de terem destruído os monumentos antigos, os góticos, pelo contrário, os conservaram com o maior dos cuidados. $\mathrm{O}$ grande Théodoric Athalaric e a rainha Amalasonthe buscaram conservar e reconstruir antigos monumentos. Borgonheses, francos e lombardos protegiam as Letras e as Artes (ÉMERIC-DAVID, 1805, pp. 399-402). O exército dos góticos, ao se expandir como uma torrente pela Grécia e Itália, “avançava entre ruínas”. Os edifícios pagãos já estavam por toda parte arruinados, e os ídolos, quebrados (Idem, [1812] 1842, p. 43). Séroux d'Agincourt protestava contra os que imputavam a decadência das artes aos bárbaros, "povos de origem setentrional, nossos grandes ancestrais" (SÉROUX D'AGINCOURT, 1823, t. I, p. 16) ${ }^{16}$. Até então, os bárbaros eram por definição um povo sem artes, pois pertenciam a um espaço que se situava fora do campo da civilização. A partir da década de 180o, se eles ainda não haviam se tornado de fato artistas, pelo menos eles não eram mais os inimigos das artes. "Resta agora a invasão dos 
bárbaros, fato enorme na questão da arte, e talvez o menos compreendido", uma vez que é aí que nasce a arte moderna, escreve em 1839 Jeanron, futuro diretor do Louvre, ao comentar Vasari ${ }^{17}$.

De fato, desde Vasari, o próprio signo da barbárie foi radicalmente invertido. Não apenas a arte não pereceu com a chegada dos bárbaros como os verdadeiros destruidores agiram muito mais diretamente e muito mais tarde do que se acreditava: "Em uma palavra, fomos fortemente persuadidos de que no século XVI viu-se renascer a pintura, dando impropriamente o nome de Renascimento à época em que essa arte começou, pelo contrário, a receber as marcas da degradação" (MONTABERT, 1829, t. III, pp. 1-2). Logo isso se tornou um leitmotiv do anticlassicismo na Europa: após o esplendor que o cristianismo conferiu às artes, o Renascimento, com o retorno ao paganismo e aos modelos romanos, somente poderia significar regressão, declínio e decadência. Victor Hugo popularizou esse tema com Notre-Dame de Paris, de 1831: desde o século XVI, a arquitetura “já não exprime mais essencialmente a sociedade. Ela se faz miseravelmente arte clássica. De gaulesa, europeia, indígena, ela se torna grega e romana; de verdadeira e moderna, pseudo-antiga. Essa decadência é o que chamamos de Renascimento” (HUGO, 1836, p. 379). 
Essa formidável inversão romântica, que foi ao mesmo tempo estética, política, racial e religiosa, é certamente indissociável da propaganda primeiramente em favor do gótico e, depois, do barroco e do expressionismo. Ela constitui a verdadeira matriz da história da arte como disciplina, uma vez que ela nasce precisamente das investidas contra o ideal clássico, o universalismo e a pretensão de não depender da história. A história da arte começa com o romantismo pela fragmentação da eternidade clássica - e essa queda da arte na consciência histórica se efetua sob o signo dos bárbaros.

Lembramos frequentemente que, até meados do século XVIII, um antiquário como o Conde de Caylus podia se maravilhar de descobrir "misturados e confundidos na mesma obra" os gostos e as maneiras de múltiplas nações (CAYLUS, 1756, t. II, pp. 23-24). Logo, entretanto, o mesmo Winckelmann que celebrava a atemporalidade do classicismo seria o primeiro a formular a ideia de que a vida de um estilo se confunde com a vida de um povo e que, consequentemente, os estilos não se misturam mais do que os povos; a transmissão das formas somente se efetua dentro dos limites nacionais e raciais. $O$ paradoxo de Winckelmann é ter simultaneamente exaltado a norma atemporal do clássico e forjado o instrumento que a destronaria. 
Dagobert Frey sublinhava em 1938 aquilo que chamaríamos hoje de etnodiferencialismo: "Com Winckelmann, pela primeira vez o 'caráter nacional' dos povos foi reconhecido como algo que se situa na origem da diferença na arte" (FREY, 1938, t. XVI, p. 3). Na História da Arte na Antiguidade, publicada em 1764, Winckelmann não somente produziu uma psicologia dos povos ou Völkerpsychologie que teria revelado o exame das obras de arte à maneira da fisiognomia, mas também fundou uma concepção biológica do estilo que o romantismo implementaria em uma busca obsessiva pela origem nacional-racial dos objetos artísticos. A prática daquilo que é necessário nomear um atribucionismo racial se desenvolveria logo no campo das belas-artes aos moldes da filo$\operatorname{logia^{18}}$. Nesse sentido, a maior parte da história da arte escrita até pelo menos meados do século XX é romântica, de Karl Schnaase a Heinrich Wölfflin, de Hippolyte Taine a Louis Courajos e de Aloïs Riegl a Henri Focillon. Todos - incluindo Focillon, que professava o antirracismo - relacionaram os objetos singulares a "estilos"; os estilos, a povos ou nações; e as nações, a conjuntos raciais ${ }^{19}$. 


\section{"A LONGA E OBSCURA INCUBAÇÃO BÁRBARA"}

Viollet-le-Duc conferia uma razão política a essa classificação racial, enquanto opunha as "civilizações políticas" às "civilizações simpáticas", cujos modelos respectivos teriam sido os romanos e os gregos - sendo estes ligados pelo sangue, segundo a mitologia das migrações arianas, às "raças indo-germânicas" civilizações que ele nomeava simpáticas se desenvolviam nas aglomerações "de homens de mesma raça ou de raças tendo entre elas certas afinidades" - , civilizações que, sozinhas, tinham artes próprias. Quanto às civilizações políticas, elas se caracterizavam pela dominação de um povo, por meio das armas e do comércio, "sobre vastos territórios ocupados por raças sem ligações entre si ou com aqueles que as dominavam. Assim era a civilização romana”. Dessa maneira, os romanos formavam "mais um corpo político e administrativo que uma nação". Da mesma forma como não existia um verdadeiro povo romano, mas apenas "uma organização romana, um governo romano", não poderia haver em Roma uma arte autêntica, mas somente "uma organização de artes pertencentes a povos estrangeiros. Uma organização perfeita [...], mas 
que não é e não pode ser a expressão do espírito de um povo". Viollet-le-Duc conclui: "Ao longo dos séculos, vemos as questões de raça e nacionalidade renascerem mais acesas e vivas do que nunca" (VIOLLET-LE-DUC, [1863] 1977, t. I, pp. 204-205) 21. Em 1919, o grande historiador da arte alemã Georg Dehio parecia concordar com Viollet-le-Duc ao descrever os caminhos divergentes que a França e a Alemanha teriam tomado a partir do século XIII: "Os franceses, conglomerado heterogêneo do ponto de vista racial e politicamente dividido, aspiram à unidade espiritual pela força. Os alemães, incomparavelmente mais unidos pelo sangue, amam acima de tudo a diversidade e elaboram de maneira cada vez mais viva a fisionomia particular de suas tribos (Stämme) e de suas paisagens" (DEHIO, [1919] 1923, t. I, pp. 212-213)22. De século em século, viam-se os mesmos contrastes oporem o modelo político de Roma, que tentava dominar o caos racial a qualquer preço, ao modelo orgânico grego - mas também "gótico" ou "romântico" - fundado sobre uma raça ou um conjunto de raças mais ou menos homogêneas.

Se Viollet-le-Duc jogou a Grécia contra Roma, exatamente como os românticos alemães haviam feito, foi por meio de leituras de Gobineau, do filtro do mito ariano e daquele da França 
das “duas raças”, forjado por Thierry e Guizot. Isso o conduziu à fabricação paradoxal de franceses simultaneamente "gregos" e "bárbaros", na medida em que os celtas tenham sido tão bárbaros quanto os antigos germanos. De origem gaulesa, com o gênio e a arte que lhe são próprios, e posteriormente dominada pelo Império Romano - "vasta organização política e administrativa, estabelecida muito mais para sufocar as tendências particulares das populações que para desenvolvê-las” -, a França havia sido regenerada pelo bom sangue ariano. "Os povos do Norte, que nos são ensinados como sendo bárbaros, deviam, pela contribuição de um sangue mais puro, dar às artes uma fisionomia particular”. Graças aos povos do Norte, o espírito racial da França, sobrevivendo à dominação de Roma, estava mais uma vez incarnado na arquitetura "dita gótica”, que, no fundo, era apenas "o despertar do velho espírito gaulês". Logo, no entanto, voltaria a dominação romana, que, com o Renascimento, reprimia o espírito da nação até meados do século XIX. Apesar de nossa língua, repetia insaciavelmente Viollet-le-Duc, apesar de nossas leis, apesar de nossa imitação detestável dos monumentos romanos, não somos latinos: somos gregos, de quem herdamos "o sentimento da forma" que quase perdemos "desde que começamos a 
imaginar que nós éramos romanos" (VIOLLET-LE-DUC, [1863] 1977, t. I, pp. 206; 240-241; 342-344; 246; 274).

No final do século XIX, Louis Courajod - católico e romântico de considerável influência - retornaria aos mesmos temas, utilizando-se por vezes das mesmas palavras que seu mestre espiritual para descrever a mesma genealogia fantástica. Mais ainda que Viollet-le-Duc, Courajod pretendia ler essa genealogia nos próprios objetos. O católico anticomunista associava, com um ódio incontrolável, Roma e a "madrasta italiana" que por duas vezes havia ceifado a França de suas raízes gregas, galesas e, sobretudo, bárbaras. Germanista ferrenho, Courajod tomava por testemunho Montesquieu contra o abade Dubos e contra todos os romanistas que, com uma "pedagogia clássica”, buscaram minimizar a importância decisiva da conquista franca na história da França e do "coeficiente bárbaro" na arte francesa. Todos os grandes partidários das teses germanistas, desde o século XVI e até a recente releitura da Germânia de Tácito por Geffroy (1874), forneciam-lhe as provas históricas de que havia ocorrido uma "conquista real, efetiva, positiva", "aberta e frequentemente violenta" pelos bárbaros de origem germânica. "Tudo se reduz a uma questão de raça”. Ele estava convencido de que desde a conquista 
romana, sobre o solo da França e no espírito francês operava-se o mais terrível dos combates "entre dois princípios intelectuais absolutamente contraditórios e eternamente inimigos: o instinto nacional e a inspiração estrangeira, a liberdade e o poder absoluto, o espírito do Norte e o espírito do Sul, o paganismo latino e o cristianismo". Courajod combatia, com todas as suas forças, o peso da Antiguidade clássica e sobretudo romana na cultura histórica, a mesma que havia conduzido à catástrofe do Renascimento, impulsionando a "decomposição do velho estilo hereditário dos povos do Ocidente" (COURAJOD, 1903, t. III, pp. 195; 159). As invasões bárbaras foram, então, centrais para sua teoria, e todo seu trabalho consistiu na afirmação de um princípio de permanência racial que, apesar das vicissitudes da história, teria assegurado a continuidade da arte galo-germano-francesa. "Entendo pelo termo bárbaro a designação coletiva de todos os povos em grande parte de origem germânica que passaram pelo território gaulês do século III ao século X. [...] Esses povos têm, entre eles, ligações de parentesco e pontos de semelhança numerosos o suficiente para que eu possa compreendê-los provisoriamente na mesma família e reunir suas culturas respectivas na mesma definição”, escreve (Ibidem, t. I, p. 28). 
Segundo Courajod, havia-se esquecido que o mundo ocidental “adormeceu pagão e romano, e despertou cristão e bárbaro". Havia-se esquecido "dos bárbaros, de quem descendemos por uma filiação indiscutível", e da potência da raça ou do "temperamento étnico", tornando por isso mesmo incompreensível a emergência do gótico. Com diversos novos estudos orientais propagando o mito ariano, Pierre Leroux já havia imaginado que os franceses haviam esquecido seus verdadeiros ancestrais, homens que, após uma longa peregrinação que os conduziu dos platôs da Ásia às terras geladas do Norte, se dispersaram em seguida, "como uma semente fecunda”, pela Alemanha, Inglaterra, Espanha e França: "Nós, homens do Norte, que deixamos nossas florestas nativas [...], esquecemos tudo isso, abandonamos nossa linhagem, repudiamos o dote que a natureza nos deu e viemos, para dizer como criancinhas que não sabem ainda falar, nos fazer herdeiros e discípulos dos romanos e gregos" (LEROUX, 1832).

A continuidade da arte francesa desde a Gália era apenas inteligível pela "longa e obscura incubação bárbara" que precede "a eclosão da escola romana" da qual o gótico foi "o filho predestinado", escreve Courajod. A noção de um tempo de incubação estava no coração de sua concepção racial da arte e de sua história. Ela 
se relacionava com os conceitos de despertar, reminiscência e sobretudo sobrevivência que ele manipulava talentosamente para constantemente lançar pontes entre os planos biológico e cultural, a fim de estabelecer a natureza hereditária da transmissão das formas no espaço e no tempo. Os "sistemas de arte circulam no mundo moral como o sangue das raças que os inventaram circula nas veias dos descendentes dessas raças" (COURAJOD, 1903, t. I, pp. 10; 169; 34; 53). Courajod não negava a sobrevida da arte antiga, mas jamais a explicava pelos mesmos argumentos de raça ou hereditariedade do sangue: para ele, essa era apenas a sobrevida de um elemento estrangeiro à cultura moderna, que era essencialmente cristã e germânica. Assim, as fíbulas e joias bárbaras dos séculos $\mathrm{V}$ e VI, cuja ornamentação ele assegurava que era comum a todas as "raças indo-germânicas", permitiam-lhe mostrar não somente a "fraternidade" das raças céltica e germânica e sua circulação através do continente europeu, mas sobretudo que o mesmo "sangue" produzia as mesmas formas com séculos de distância. Como testemunha, a decoração romana e gótica, que provava a “transmissão ininterrupta e direta do princípio familial". A decoração industrial dos bárbaros era antes de tudo "uma arte de raça, uma longínqua herança de família" que provinha "da velha 
incubação indiana e asiática”, dado que no fundo "todos os povos de origem ariana beberam de uma fonte comum" (COURAJOD, 1903 , t. I, pp. $213 ; 185 ; 186)$.

Certamente se deve a Courajod o fato de, a partir de uma noção indissociavelmente biológica e cultural da "sobrevivência”, terem-se reunidos os ingredientes necessários à tese da continuidade étnica ou racial dos "estilos" que invadiria a história da arte francesa e alemã da primeira metade do século XX.

\section{O KUNSTWOLLEN DOS GERMANOS E 0 TEMPO ESTRATIFICADO}

Longe de rejeitar a herança de Roma em favor do Oriente, como fazia Courajod ou como faria Josef Strzygowski em seguida, Aloïs Riegl via, ao contrário, no equilíbrio das "orientações da arte germana e latina" uma "missão mundial" à qual se propôs especialmente o barroco (RIEGL, 1908, p. 6) ${ }^{24}$. No entanto, ele julgava também que a civilização dos italianos e a dos povos germânicos eram, "até os nossos dias", de um antagonismo radical (Idem, 1978, p. 185). Além disso, ele via na oposição entre a cultura do Oriente antigo semítico [der altorientalisch-semitischen Kultur] e a cultura indo-germânica o conflito que havia dominado 
a evolução da humanidade, com Roma situada entre esses dois "extremos". O verdadeiro progresso, porém, vinha sempre dos povos indo-germânicos (Idem, [1900] 1995, pp. 71-90). Essa visão radical, que atravessou a maior parte de seus trabalhos, estava no cerne de sua principal obra, Die spätrömische Kunstindustrie nach den Funden in Österreich-Ungarn, que devia ser implantada em duas partes: a primeira seria uma investigação sobre o destino das artes industriais a partir do século III da era cristã no seio dos povos do Mediterrâneo que, até então, estiveram à frente do desenvolvimento da civilização. A segunda devia determinar a parte dos povos bárbaros do Norte na formação das belas-artes durante os cinco séculos e meio que separavam Constantino de Carlos Magno (RIEGL, 1901, p. 1). Somente a primeira parte foi publicada em vida, em 1901. Diz-se geralmente que Riegl buscava mostrar que o distanciamento do ideal clássico não se devia em nada à nova composição étnica do Baixo-Império romano consecutivo às invasões bárbaras: aquilo que se classificava até então como degeneração do classicismo constituía muito mais a emergência de um estilo novo, correspondente a um novo Kunstwollen ${ }^{25}$. No entanto, como ele buscava demonstrar que a cada raça correspondia um Kunstwollen distinto, os resultados foram de uma profunda ambiguidade. 
A segunda parte, cujo texto provém de suas aulas ministradas na Universidade de Viena, foi publicada em 1923, com uma interessante introdução de sua autoria que foi em geral bastante ignorada. Riegl esboçava um paralelo marcante entre o destino político e o destino artístico da romanidade tardia durante as invasões germânicas. Assim como "os eventos políticos da migração dos povos eram principalmente consequência do Querer [des Willens] dos romanos (mesmo que inconscientemente), [...] as produções artísticas da época da migração dos povos eram principalmente consequência do Querer estético [des ästhetischen Wollens] dos romanos". Portanto, seria impossível falar da arte desse período como uma arte "bárbara". Por outro lado, a arte antiga já estava "barbarizada" desde antes da chegada dos germanos na história da civilização, por volta de 375 . O caráter clássico estava se perdendo, aproximando-se do gosto inferior dos bárbaros germânicos. Contudo, segundo Riegl, vemos, no século IV, “reações clássicas contínuas ao impulso da evolução rumo ao cristianismo (ou seja, o culto de um deus crucificado como religião de Estado). Os romanos lembram-se de tempos em tempos do passado e não querem abandoná-lo. Eles querem impedir a evolução à força. Já se vê que o elemento dito bárbaro [das sogenannte Barbarische] 
se tornou então o elemento propriamente de progresso [das eigentliche Fortschrittliche]. E exatamente como no plano político, também no plano artístico foram os germanos que intervieram e cortaram o retorno aos Antigos e provocaram uma virada decisiva para uma arte construída sobre princípios novos, não antigos”. Assim, apenas após a migração dos povos tornou-se possível diferenciar o Kunstwollen dos germanos do Kunstwollen dos povos latinos. Essa diferença, no entanto, devia "apesar de tudo estar presente na época da migração dos povos, e o fato de que ela não é identificável à primeira vista não nos libera do dever de buscar esse conhecimento" (RIEGL, 1923, pp. 6-7).

Otto Pächt, um dos mais fervorosos discípulos de Riegl, nota que a preferência de Riegl pelas artes do Norte é clara, apesar de sua suposta neutralidade (PÄCHT, 1963, p. 191). Tratava-se de um eufemismo. Todo o dispositivo teórico construído por Riegl desde 1898, exposto claramente na Grammaire historique des arts plastiques, visava demonstrar o papel motor dos "povos de raça germânica" na evolução geral da cultura ocidental e na evolução da arte em particular. É estarrecedor ver o imenso e duradouro sucesso que essas teses atingiram, especialmente quando se leva em consideração a fragilidade de alguns dos princípios sobre os 
quais elas se fundam. É assim que a oposição tão frutífera entre o caráter "táctil” (ou "háptico") e a "opticidade" dos objetos artísticos formulada pelo escultor Adolf von Hildebrand em 1893 foi projetada por Riegl simultaneamente na história e na psicologia das raças (VON HILDEBRAND, 1893) ${ }^{27}$. Inspirando-se em uma tradição romântica alemã, ele transformava de maneira decisiva os conceitos de "visão próxima" (Nahbild) e de "visão distanciada" (Fernbild) elaborados por Hildebrand, adicionando a eles o conceito de "visão normal" (Normalsicht). Quando Hildebrand se esforçava para diferenciar "os dois modos de percepção dos quais podemos dispor", era na qualidade de artista, preocupado em justificar suas próprias escolhas artísticas. Em nome da experiência, ele se utilizava dessas categorias perceptivas: para ele, toda experiência da forma plástica derivava necessariamente de sua percepção por uma "palpação", fosse ela "operada pela mão ou pelo olho" (Idem, 2002, p. 35). São tais categorias puramente fenomenológicas que Riegl projetaria numa história, psicologia e geografia raciais herdadas do romantismo.

Em 1901, Riegl situava a tatilidade como aquilo que era próprio da arte antiga mediterrânea, ao passo que a opticalidade era própria da arte moderna do Norte. Assim, ele transformava 
os dois conceitos em critérios plásticos da oposição entre os dois modelos culturais latino e germano, racialmente determinados. Como sublinhava em 1934 Julius von Schlosser, antigo colega da Universidade de Viena, Riegl tomava o caminho de uma "duvidosa psique das raças" que se encontrava "hipostasiada na oposição do óptico e do háptico" (VON SCHLOSSER, 1934, caderno 2, pp. $186 / 42)^{28}$. No entanto, essas qualidades plásticas opostas que ele conferia aos objetos artísticos não eram somente os produtos de psicologias sociais diferentes. Na primeira parte de Spätrömische Kunstindustrie, Riegl afirma que elas eram os produtos de disposições biológicas que exigiam suas próprias respostas artísticas: "A percepção sensível [que os antigos tinham] mostrava-lhes os objetos exteriores de maneira pouco clara, confusa e misturada. Por meio das artes plásticas, eles os apreendiam individualmente e os dispunham em sua unidade clara e fechada. O objetivo final das artes plásticas de toda a Antiguidade era restituir os objetos exteriores em sua clara unidade material" (RIEGL, 1901, p. 17) 29.

Em virtude de um tipo de teoria da recapitulação, Riegl presumia que os homens da Antiguidade fossem tão deficientes sensorialmente quanto um recém-nascido. Meyer Schapiro nota que o hegelianismo e o evolucionismo de Riegl o levaram a descrever 
um processo histórico no qual "cada grande fase corresponde a uma disposição racial”. Assim, Riegl podia igualmente sustentar a ideia de que, após dois séculos de dominação no Ocidente, a arte francesa teve que "ceder o primeiro lugar a povos germânicos, cuja consciência de raça se manteve mais pura” (Idem, 1978, p. 47). Os "povos de raça germânica”, mais espirituais e mais “ópticos" que os povos mediterrâneos, eram naturalmente convocados a ocupar o topo da evolução.

O historiador da arte francês Henri Focillon, no entanto, designava-lhes exatamente a posição inversa na cadeia de evolução, afirmando que os antigos germanos pertenciam de alguma maneira à pré-história ou à "proto-história”, e não estava longe de pensar o mesmo dos alemães do século XX. Focillon recusava qualquer concepção linear de evolução: assim como a história era de saída "um conflito de precocidades, de atualidades e de atrasos”, a história da arte também apresentava, “justapostas no mesmo momento, sobrevivências e antecipações, formas lentas, retardatárias, contemporâneas de formas ousadas e rápidas" (FOCILLON, [1934] 1970, pp. 86-87), uma vez que "todas as regiões de um tempo não vivem numa mesma época" e "o próprio presente era sempre infinitamente estratificado" (FOCILLON, 
1931, p. 15). Hoje, o que perturba é a regularidade com a qual a exposição dessas concepções então novas da estrutura do tempo histórico se aproximava, em seus trabalhos, tanto da evocação da "noção de raça" quanto da dos bárbaros de então e de antes. A visão sedutora de uma história tecida de sobrevivências e de antecipações parece nascida das reflexões sobre a temporalidade dos bárbaros, em resposta às teorias raciais que professavam então alguns de seus colegas alemães.

Em 1915, ele condenaria os alemães por terem fundado seu império sobre "a noção de raça [...] que a antropologia objetiva não aceita mais como princípio científico" e por terem "restaurado esse termo ultrapassado". No entanto, ele logo se contradiria ao apresentar a arte do Império alemão como o programa de uma raça e o resumo de seus instintos: "Uma onda de barbárie surgida em plena civilização, no próprio coração do Ocidente” (Ibidem, [1915] 1932, p. 175). Segundo Focillon, essa raça atrasada se utiliza, no fundo, de uma noção obsoleta para prolongar seu próprio passado e ressuscitar o bárbaro que nela estava adormecido. Ele, que pretendia sinceramente lutar contra as discriminações sociais, se utilizava com uma obstinação impressionante da "noção de raça" em sua acepção mais biológica. Como muitos de seus contemporâneos 
antirracistas, ele acreditava na realidade da raça: "Eles concretizaram essa força movente", escreve Focillon sobre seus inimigos, cujos preconceitos raciais ele buscava combater.

Criado sob a memória da Guerra Franco-Prussiana de 1870 e morto nos Estados Unidos em 1941 após ter passado pela Primeira Guerra Mundial, Focillon pertencia a uma geração de franceses para a qual essas guerras haviam sido como um lembrete, se não o retorno, das "grandes invasões germânicas". Toda a parte de sua obra dedicada à Idade Média - a mais importante - foi um comentário a essas invasões bárbaras, chegando à exaltação patriótica dos últimos textos nos quais ele estigmatizava uma Alemanha "incerta de sua forma geográfica, política e moral", "assombrada pela nostalgia instintiva do que chamamos 'as invasões', migrações em massa dos povos bárbaros” (Ibidem, [1940] 1945, p. 51).

Assim como ao longo dos embates que travou em 1932 e $1934^{30}$ com o austríaco Josef Strzygowski - o mais fanático dos historiadores da arte racistas e inimigo íntimo de Aloïs Riegl -, Focillon desenvolveu em A Vida das formas um argumento notável. Ele não desejava submeter mais uma vez à crítica "a velha noção de raça, sempre sujeita à confusão entre a etnografia, a 
antropologia e a linguística”. A raça não era estável, tampouco constante, e em lugar algum poderiam existir "conservatórios de raças puras”. Seria necessário, contudo, levar em consideração os "antigos depósitos do tempo" dos quais a arte por vezes tomava emprestado um "estranho relevo": "Eles surgem como blocos erráticos, testemunhas do passado, numa paisagem pacificada". Assim, mesmo que as "famílias espirituais" pudessem sobrepor sua rede à das raças, era possível associar as raças e os conjuntos formais: "Certos blocos formais não são a língua autêntica de certas raças? Não há no entrelaçado uma imagem e um signo de um modo de pensamento próprio aos povos do Norte? Mas o entrelaçado - e, de maneira mais geral, o vocabulário geométrico - pertence comumente a toda a humanidade primitiva e, quando eles reaparecem no começo da Alta Idade Média, quando eles recobrem o antropomorfismo mediterrâneo e o desnaturam, trata-se bem menos do choque de duas raças que do encontro de dois estados do tempo ou, para ser mais claro, de dois estados do Homem" (FOCILLON, [1934] 1970, p. 88-89, grifo nosso).

O evolucionismo de Focillon - menos linear que o de Riegl não designava a cada raça um lugar definido na história, dado que sua ideia de uma estratificação do tempo introduzia na história da 
arte o equivalente daquilo que Ernst Bloch $(1978$, p. 218) chamava, no mesmo momento, de irrupção do "não contemporâneo" no presente. No entanto, ele também não deixava de praticar um essencialismo ou um diferencialismo racial que se religava à ideia da perfectibilidade limitada de certas raças que o século XIX havia defendido, de maneira que essas raças permaneciam atadas às mesmas formas ao longo de toda a história.

Certamente as invasões bárbaras constituiriam, desde o começo do século XIX, o lugar e o tempo míticos a partir dos quais seria possível uma história da arte não clássica. Se Winckelmann foi "o primeiro a ter ousado decompor a Antiguidade" (QUATREMĖRE DE QUINCY, [1796] 1989, p. 103) ao analisar os tempos, os povos e os estilos dos antigos, resta ainda "decompor" aquilo que não era nem Antiguidade nem seu renascimento. Seria necessário, para sair da eternidade do classicismo, ou seja, de seu valor de norma, inventar temporalidades novas que não sejam nem as das Vidas de artistas ao estilo de Vasari nem as das dinastias pelas quais foram escritas as histórias nacionais. As invasões bárbaras, momento de gênese dos povos europeus modernos, se ofereceram aos românticos e a um número de seus sucessores como o modelo de um recomeço absoluto. Mas o preço 
a se pagar foi a construção de outras eternidades que seriam de algum modo paralelas e concorrentes à primeira: as "raças" que lhes serviram de apoio.

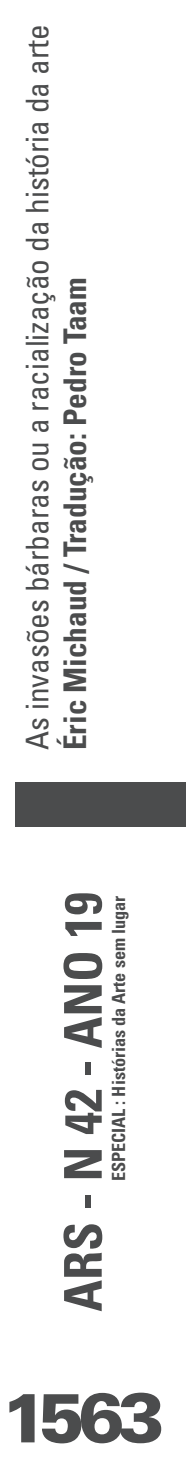




\section{NOTAS}

1. Sobre a construção e os desenvolvimentos ideológicos e políticos da "raça latina" na França no séculoXIX, ver PANICK (1978). Sobre a polissemia do termo "bárbaro" na literatura romântica francesa, ver MICHEL (1981), DROIT (2007).

\section{Ver HAMILTON (1977).}

3. A carta de 7 mai. 1799 se encontra em WALZEL (1890, p. 421).

4. Ver principalmente as lições I e XIII de SCHLEGEL (1814).

5. Ver MARCHAND (1996, p. 158). De Staël estabelece em 1800 (De la littérature...) uma geografia literária que diferencia os "dois hemisférios": "Parece-me que existem duas literaturas totalmente distintas, a que vem do Sul e a que descende do Norte, aquela cuja primeira fonte é Homero e aquela da qual a origem é Ossian". De Staël, no entanto, não faz qualquer consideração quanto a raças.

6. Sabe-se que essas características eram exatamente as que Tácito havia atribuído aos germanos para melhor opô-los à depravação geral da qual acusava os romanos do império.

\section{Ver ISBELL (1994).}

8. Carta de Caspar David Friedrich ao professor Schulz, datada de 8 jan. 1809, in HINZ (1968, p. 156).

9. Sobre o papel essencial na construção da identidade alemã desempenhado pela Germânia escrita pelo “romano” Tácito no fim do século I, ver WERNER (2001, pp. 569-586).

10. BOULAINVILLIERS (1727, t. I, pp. 29-33), BLOCH (1940, t. XIX), ARENDT ([1951] 1979, pp. 164-165), DEVYVER (1973), FOUCAULT (1997), POMIAN (1997), NICOLET (2003), WOOD (2008). 
11. Sabe-se que foi aqui, em Augustin Thierry e Guizot, que Marx e Engels encontraram as primeiras formulações da luta de classes.

12. Mike Rowlands (1989) afirma que a imagem do bárbaro mudou radicalmente nos anos 1870-1895. Nossa hipótese é que ela logo teria sido modificada em reação à Revolução Francesa e ao imperialismo napoleônico.

\section{Ver HARTOG (2005).}

14. Meus agradecimentos a Mary Nyquist por ter me lembrado desse texto fundamental.

15. No original: “Questa maniera fu trovata da Goti, che per avere ruinate le fabbriche antiche, e morti gli architetti per le guerre, fecero dopo coloro che rimasero le fabbriche di questa maniera".

16. Séroux começa a elaboração de sua obra na década de 1780 e publica-a mensalmente em partes a partir de 1810.

17. Philippe Auguste Jeanron, comentário sobre a vida de Don Giulio Clovio, in VASARI (1839, t. V, pp. 180; 200-202).

18. Sobre o papel da política da filologia no século XIX, ver GEARY (2002, pp. 15-40).

19. Nota-se novamente quanto as categorias de nação e raça são altamente permeáveis e comunicam-se constantemente - em todas a línguas europeias e por um longo tempo - com as categorias de povo, povoado, tribo e etnia.

20. Ver POLIAKOV (1987). Sobre a convicção de Viollet-le-Duc quanto às relações da arte com as migrações arianas, ver o artigo "Sculpture" do Dictionnaire raisonné de l'architecture française du $\mathrm{Xl}^{e}$ au $X V l^{e}$ siècle (DICTIONNAIRE, 1866, t. VIII, pp. 274; 189-190). Ver também BARIDON (1996).

21. Viollet-le-Duc, que propositalmente faz referência a Gobineau na oitava parte ([1863] 1977 , t. I, p. 342, nota 1), também toma-Ihe emprestada a noção da nulidade cultural de Roma 
em razão da ausência de uma raça romana. Por exemplo: “Roma não tinha nada próprio, nem religião, nem lei, nem língua, nem literatura..." (VIOLLET-LE-DUC, 1855, t. III, p. 315).

22. Reconhecendo as origens "francesas" do gótico, Dehio ([1919] 1923, p. 215) via-o como produto de uma época, e não de raça: como saber a que componente racial da França galesa, romana ou germânica - ele se deveria?

23. As aulas ministradas por Courajod notavelmente inspirariam a grande e influente Histoire de l'art, de André Michel, tanto que Paul Vitry, seu aluno, difundiria o pensamento do mestre até o fim da década de 1930. As teorias raciais de Courajod que identificavam o cristianismo com o gênio nórdico-oriental seriam retomadas e amplamente propagadas nos países de língua alemã por Josef Strzygowski. Ver FRANCASTEL (1945, pp. 130-131).

24. Ver OLIN (1994).

\section{Esta leitura canônica é de PÄCHT (1963).}

26. Entre os raros trabalhos que mencionam a segunda parte, há o importante texto de WOOD (2004). Sua interpretação, no entanto, difere bastante da nossa: para Wood, que também cita essa última frase, Riegl assegura que não houve necessidade de qualquer contribuição étnica estrangeira para que Roma se tornasse a fonte da modernidade. Riegl, no entanto, escreve que os germanos foram os responsáveis pela "virada decisiva" rumo a uma arte fundada em princípios não antigos.

\section{Ver OLIN (1992, pp. 134-137), IVERSEN (1993, pp. 73-76).}

28. Tal oposição ainda relacionava Riegl ao romantismo: de Schiller a A.W. Schlegel e De Staël, a escultura era a arte do paganismo antigo, e a pintura, a da modernidade cristã: um topos que, após Hegel, seria comumente aceito. Ver também WOOD (2000, pp. 26-27).

29. No original: “Ihre sinnliche Wahrnehmung zeigte ihnen die Außendinge verworren und unklar untereinander vermengt; mittels der bildenden Kunst griffen sie einzelne Individuen heraus und stellten sie in ihrer klaren abgeschlossenen Einheit hin. Die bildende Kunst des gesamten Altertums hat somit ihr letztes Ziel darin gesucht, die Außendinge in ihrer klaren 
stofflichen Individualität wiederzugeben". Ver a tradução francesa de Marielène Weber (RIEGL; WOOD; ALLOA, 2014, p. 77).

30. ČAPEK (1932), FOCILLON; MURRAY; STRZYGOWSKI et. al. (1935). Ver ARRECHEA MIGUEL (1993).

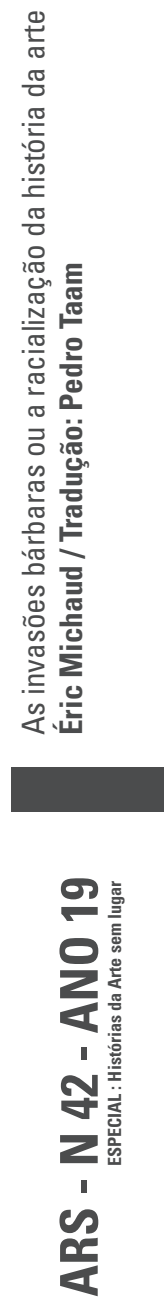

1567 


\section{REFERÊNCIAS BIBLIOGRÁFICAS}

ARENDT, Hannah. As origens do totalitarismo: antissemitismo, imperialismo, totalitarismo / trad. Roberto Raposo. São Paulo: Companhia das Letras, 2012.

ARRECHEA MIGUEL, Julio. Focillon y Strzygowski o la lejana raíz del arte occidental, Espacio, Tiempo y Forma, Serie VII, Ha. del Arte, t. VI, 1993, pp. 559-606.

BARIDON, Laurent. L'Imaginaire scientifique de Viollet-le-Duc. Paris: L'Harmattan, 1996.

BLOCH, Ernst. Héritage de ce temps / trad. J. Lacoste. Paris: Payot, 1978.

BLOCH, Marc. Sur les grandes invasions, Revue de synthèse, t. XIX, 1940, pp. 55-82.

BOISSERÉE, Sulpice. Histoire et description de la cathédrale de Cologne (1823), nouvelle édition. Munich: Institut de Littérature et des Arts, 1843.

BOULAINVILLIERS, Comte de. Histoire de l'ancien gouvernement de la France. La Haye/Amsterdam: Aux Dépens de la Compagnie, 1727.

ČAPEK, Karel. Entretiens sur Goethe à l'occasion du centenaire de sa mort. Paris: Société des Nations, Institut international de coopération intellectuelle, 1932. 
CAYLUS, Comte de. Recueil d'antiquités égyptiennes. Paris: Duchesnes, 1756.

CÉSAIRE, Aimé. Discours sur le colonialisme. Paris: Présence Africaine, 1955.

CHASLES, Philarète. Études sur l'Allemagne ancienne et moderne. Paris: Librairie d'Amyot, 1854.

CHATEAUBRIAND, F.-R. de Chateaubriand. Essais sur les révolutions (1797). In CHATEAUBRIAND, F.-R. de Chateaubriand. Cuuvres complètes, t. II, 1. Paris: Pourrat Frères, 1836.

COURAJOD, Louis. Leçons professées à l'École du Louvre (1887-1896). Paris: Picard, 1903.

D’ECKSTEIN, Baron. De la littérature dramatique chez les modernes, Le Catholique, Paris, Sautelet et Cie, 1826.

DEHIO, Georg. Geschichte der deutschen Kunst (1919). Berlin/Leipzig: Walter de Gruyter \& Co., 1923.

DE STAËL, Madame. De l'Allemagne. (1813). Paris: Firmin Didot, frères, fils et cie., 1859.

DEVYVER, André. Le Sang épuré. Les préjugés de race chez les gentilshommes français de l'Ancien régime (1560-1720). Bruxelles: Éditions de l'Université libre de Bruxelles, 1973. 
DICTIONNAIRE raisonné de l'architecture française du $\mathrm{Xl}^{\mathrm{e}}$ au $\mathrm{XVl} \mathrm{l}^{\mathrm{e}}$ siècle. Paris: A. Morel, 1866.

DROIT, Roger-Pol. Généalogie des barbares. Paris: Odile Jacob, 2007.

ÉMERIC-DAVID, Toussaint-Bernard. Recherches sur l'art statuaire, considéré chez les Anciens et chez les Modernes. Paris: Nyon Aîné, 1805.

ÉMERIC-DAVID, Toussaint-Bernard. Histoire de la peinture au Moyen Âge (1812) / éd. P. L. Jacob (Paul Lacroix). Paris: Gosselin, 1842.

FOCILLON, Henri. L'Art des sculpteurs romans. Recherches sur l'histoire des formes. Paris: E. Leroux, 1931.

FOCILLON, Henri. L'art allemand depuis 1870 (1915). In FOCILLON, Henri. Technique et sentiment (1919). Paris: Société de Propagation des Livres d'Art, 1932.

FOCILLON, Henri; MURRAY, Gilbert; STRZYGOWSKI, Josef et.al. Correspondance

4. Civilisations. Orient - Occident, Génie du Nord - Latinité. Lettres de Henri Focillon, Gilbert Murray, Josef Strzygowski, Rabindranath Tagore. Paris: Société des Nations, Institut international de Coopération intellectuelle, 1935.

FOCILLON, Henri. Vie des formes (1934). Paris: PUF, 1970. 
FOCILLON, Henri. "Fonction universelle de la France" (discurso proferido no Carnegie Hall, Nova York, em 20 dez. 1940). In FOCILLON, Henri. Témoignage pour la France. Nova York: Brentano's, 1945.

FOUCAULT, Michel. II faut défendre la société. Cours au Collège de France, 1976. Paris: Gallimard/Seuil, 1997.

FRANCASTEL, Pierre. L'Histoire de l'art, instrument de la propagande germanique. Paris: Médicis, 1945.

FREY, Dagobert. Die Entwicklung nationaler Stile in der mittelalterlische Kunst des Abendlandes, Deutsche Vierteljahrsschrift für Literaturwissenschaft und Geistesgeschichte, t. 16, 1938.

GEARY, Patrick. A Poisoned Landscape: Ethnicity and Nationalism in the Nineteenth Century. In GEARY, Patrick. The Myth of Nations. The Medieval Origins of Europe. Princeton: Princeton University Press, 2002, pp. 15-40.

GEFFROY, Auguste. Rome et les Barbares. Étude sur la Germanie de Tacite. Paris: Didier, 1874.

GUIZOT, François. Du gouvernement de la France depuis la Restauration, et du ministère actuel. Paris: Ladvocat, 1820. 
HAMILTON, James F. Structural Polarity in Mme. de Staël's De la littérature, The French Review, vol. 50, n. 5 (abr. 1977), pp. 706-712.

HARTOG, François. Anciens, Modernes, Sauvages. Paris: Galaade, 2005.

HERDER, J. G. Une autre philosophie de l'histoire (1774) / Trad., introdução e notas Max Rouché. Paris: Aubier, 1943.

HINZ, Sigrid (org.). Caspar David Friedrich in Briefen und Bekenntnissen. Berlin: Henschel, 1968.

HUGO, Victor. Guvres, t. I. Bruxelles: Meline, 1836.

ISBELL, John Claiborne. The Birth of European Romanticism. Truth and Propaganda in Staël's De l'Allemagne. Cambridge: Cambridge University Press, 1994.

IVERSEN, Margaret. Alois Riegl: Art History and Theory. Cambridge, MA/ London: MIT Press, 1993.

LEROUX, Pierre. De l'influence philosophique des études orientales, Revue encyclopédique, 1832, pp. 69-82.

MARCHAND, Suzanne L. Down from Olympus. Archaeology and Philhellenism 
in Germany, 1750-1970. Princeton, New Jersey: Princeton University Press, 1996.

MICHEL, Pierre. Un mythe romantique. Les Barbares, 1789-1848. Lyon: Presses Universitaires de Lyon, 1981.

MICHELET, Jules. Histoire Romaine. Première partie: République, t. I. Paris: Hachette, 1831.

MOISY, Pierre. Les Séjours en France de Sulpice Boisserée (1820-1825). Lyon/ Paris: IAC, 1956.

MONTABERT, J. N. Paillot de. Traité complet de la peinture, t. III. Paris: J.-F. Delion, 1829.

MONTESQUIEU. De l'Esprit des lois. Genève: Barillot et Fils, 1748.

NICOLET, Claude. La Fabrique d'une nation. La France entre Rome et les Germains. Paris: Perrin, 2003.

OLIN, Margaret. Forms of Representation in Alois Riegl's Theory of Art. University Park: The Pennsylvania State University Press, 1992.

OLIN, Margaret. Alois Riegl: The Late Roman Empire in the Late Habsburg Empire. In ROBERTSON, Ritchie; TIMMS, Edward (orgs.). The Habsburg Legacy. National Identity in Historical perspective. Edimburgo: Edinburgh University Press, 1994, pp. 107-120. 
PÄCHT, Otto. Alois Riegl, The Burlington Magazine, vol. 105, n. 722 (mai. 1963), pp. 188-193.

PANICK, Käthe. La Race latine. Politischer Romanismus im Frankreich des 19. Jahrhunderts. Bonn: Ludwig Röhrscheid Verlag, 1978.

POLIAKOV, Léon. Le Mythe aryen. Essai sur les sources du racisme et du nationalisme. Nouvelle édition augmenté. Bruxelles: Complexe, 1987.

POMIAN, Krzysztof. Francs et Gaulois (1992). In NORA, Pierre (org.). Les Lieux de mémoire, 2. Paris: Gallimard (Quarto), 1997, pp. 2245-2300.

QUATREMÈRE DE QUINCY, Antoine C. Lettres à Miranda sur le déplacement des monuments de l'art de l'Italie (1796) / éd. Édouard Pommier. Paris: Macula, 1989.

RENAN, Ernest. La Réforme intellectuelle et morale. Paris: Michel Lévy Frères, 1871.

RIEGL, Alois. Die spätrömische Kunst-Industrie nach den Funden in ÖsterreichUngarn im Zusammenhange mit der Gesamtentwicklung der bildenden Künste bei den Mittelmeervölkern. Wien: Österreichisches Archäologisches Institut, 1901.

RIEGL, Alois. Die Entstehung der Barockkunst in Rom / orgs. A. Burda; M. Dvořák. Wien: Anton Schroll, 1908. 
RIEGL, Alois. Die Spätrömische Kunst-Industrie nach den Funden in Österreich-Ungarn, t. II: Kunstgewerbe des frühen Mittelalters auf Grundlage des Nachgelassenen Materials Alois Riegls / org. E. Heinrich Zimmermann. Viena: Österreichisches Archäologisches Institut, 1923.

RIEGL, Alois. Grammaire historique des arts plastiques (ca. 1897-1898) / trad. fr. E. Kaufholz. Paris: Klincksieck, 1978.

RIEGL, Alois. Zur kunsthistorischen Stellung der Becher von Vafio (1900). In RIEGL, Alois. Gesammelte Aufsätze. Berlim: Gebr. Mann Verlag, 1995, pp. 71-90.

RIEGL, Alois; WOOD, Christopher S; ALLOA, Emmanuel. L'Industrie d'art romaine tardive / Trad. Marielène Weber. Paris: Macula, 2014.

ROWLANDS, Mike. European Barbarism and the Search for Authenticity. In HARBSMEIER, Michael; LARSEN, Mogens Trolle (org.). The Humanities between Art and Science. Intellectual Developments, 1880-1914. Copenhaguen: Akademisk Forlag, 1989, pp. 225-239.

SCHLEGEL, August Wilhelm. Cours de littérature dramatique, t. I; II. Paris/ Genève: Paschoud, 1814.

SCHLEGEL, Friedrich. Briefe auf einer Reise durch die Niederlande, Rheingegenden, die Schweiz, und einen Theil von Frankreich. In SCHLEGEL, 
Friedrich. Poetisches Taschenbuch für das Jahr 1806. Berlin: Unger, 1806, p. 267; 278.

SCHLEGEL, Friedrich. Über die neuere Geschichte: Vorlesungen gehalten zu Wien im Jahre 1810. Wien: Karl Schaumburg und Comp., 1811.

SCHLEGEL, Friedrich. Tableau de l'histoire moderne de Frédéric Schlegel / trad. M. J. Cherbuliez. Paris: Eugène Renduel/ Genève: Abraham Cherbuliez, 1831.

SÉROUX D'AGINCOURT, J. B. L. G. Histoire de l'art par les monuments, depuis sa décadence au IV ${ }^{e}$ siècle jusqu'à son renouvellement au $X V{ }^{e}$. Paris: Treuttel et Würtz, 1823.

SIEYÈS, Joseph Emmanuel. Qu'est-ce que le Tiers-État? (1789) / org. Edmé Champion. Paris: Société d'histoire de la Révolution française, 1888.

THIERRY, Augustin. Histoire de la conquête de l'Angleterre par les Normands (1825). In THIERRY, Augustin. Cuures complètes, t. I. Paris: Furne et Cie, 1846.

THIERRY, Augustin. Sur l'antipathie de race qui divise la nation française (1820). In THIERRY, Augustin. Dix ans d'études historiques, Fuvres complètes, t. VI. Paris: Furne et Cie, 1851, pp. 236-243.

VASARI, Giorgio. Vies des plus célèbres peintres, sculpteurs et architects / trad. L. Leclanché. Paris: Tessier, 1839. 
VASARI, Giorgio. De l'architecture. In VASARI, Giorgio. Les Vies des meilleurs peintres, sculpteurs et architects / trad. e org, t. I. A. Chastel. Paris: BergerLevrault, 1981.

VIOLLET-LE-DUC. Entretiens sur l'architecture. Bruxelles: Mardaga, 1977.

VIOLLET-LE-DUC. Essai sur l'inégalité des races humaines. Paris: Firmin Didot, 1855.

VON HILDEBRAND, Adolf. Le Problème de la forme dans les arts plastiques / trad. E. Beaufils. Paris: L'Harmattan, 2002.

VON SCHLOSSER, Julius. Die Wiener Schule der Kunstgeschichte, Mitteilungen des Österreichischen Instituts für Geschichtsforschung, vol. XIII, caderno 2. Innsbruck: Universitäts-Verlag Wagner, 1934, pp. 186/42.

WALZEL, Oskar (org). Friedrich Schlegels Briefe an seinen Bruder August Wilhelm. Berlin: Speyer \& Peters, 1890.

WERNER, Michael. Die Germania, in FRANÇOIS, Étienne; SCHULZE, Hagen (org.). Deutsche Erinnerungsorte, Bd. III. Munich: Beck, 2001, p. 569-586.

W00D, Chris. Riegl's Mache, Res 46, outono 2004, pp. 155-172. 
W00D, Christopher Wood (org.). The Vienna School Reader, Politics and Art Historical Method in the 1930s. New York: Zone Books, 2000.

WOOD, Ian. Barbarians, Historians, and the Construction of National Identities, Journal of Late Antiquity, 1, 2008, pp. 61-81.

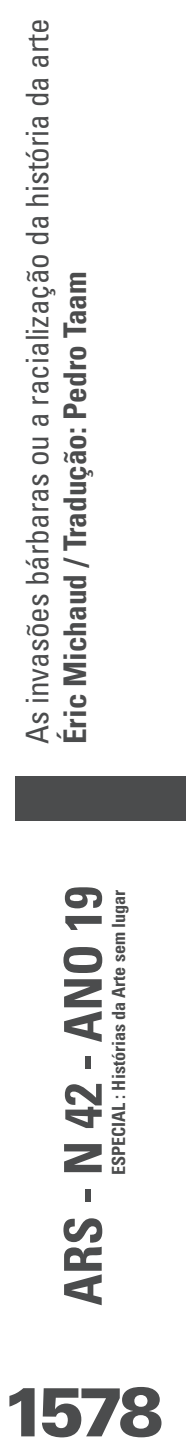


Éric Michaud é Directeur d'études na Ecole des hautes études en sciences sociales, em Paris, onde ocupa a cátedra de Histórias e Ideologias da Arte Contemporânea. Entre 1972 e 1998, foi professor assistente e professor associado na Marc Bloch University, em Estrasburgo. Foi professor visitante na The Johns Hopkins University, na Duke University e na University of Virginia, todas nos Estados Unidos, além de ter sido contemplado com a Institute for Advanced Study Membership (Princeton, 2010), a Clark Art Institute Fellowship (Williamstown, 2014) e a Getty Resarch Institute Fellowship (Los Angeles, 2015). Publicou livros como Les invasions barbares. Une généalogie de l'histoire de l'art (Paris, Gallimard, 2015), Histoire de I'art: une discipline à ses frontières (Paris, Hazan, 2005), Fabriques de l'homme nouveau, de Léger à Mondrian (Paris, Carré, 1997). 


\section{SOBRE 0 TRADUTOR}

Pedro Taam é pianista, tradutor e editor. É bacharel em filosofia pela Universidade de São Paulo e doutorando em filosofia na Pontifícia Universidade Católica de São Paulo. Traduziu, entre outros, Os Tempos Modernos, de Jacques Rancière, e é editor das coleções Clássicos e Métodos na editora WMF Martins Fontes. 